\title{
Energy Demands Estimation in Certain Districts of South Bihar for Irrigation Operations
}

\author{
Akanksha* and Indu Bhushan Bhagat \\ Department of Irrigation and Drainage Engineering, College of Agricultural Engineering, \\ Dr. Rajendra Prasad Central Agricultural University, Pusa, Samastipur, Bihar-848125, India \\ *Corresponding author
}

\section{A B S T R A C T}

During the $21^{\text {st }}$ century adoption of electric motor for irrigation operation will be much more resulting a sharp rise in demand for electricity. The electricity requirement for planning, design and operation of irrigation and water resources systems is necessary. It is a parameter of prime importance in formulating the policy for distribution of electricity as well as decision making in day by day operation and management of electricity

\section{Keywords}

Energy requirement, Ground water pumpage, Crop evapotranspiration

Article Info

Accepted: 15 January 2018 Available Online: 10 February 2018 distribution network. The study was done for the year 2010-11. Average rainfall of the selected districts Arwal, Nawada, Gaya, Jehanabad, and Aurangabad varies from 950 to $1100 \mathrm{~mm}$. Maximum temperature rise upto $45^{\circ} \mathrm{C}$ and minimum falls to $2^{\circ} \mathrm{C}$. The study was conducted on maize, rice, wheat, sugarcane and potato crops. The cropping intensity of the Bihar state was found $146 \%$. Information about area cultivated under different crop, cropping system, crop yields, rainfall, climatic parameters, water table depth below ground surface were obtained from different Departments. These data were used to calculate the electricity requirements by using ENIRRMOD (Energy IRRigation MODel) model for irrigation operation. Total ground water pumpag required in study area was found 33.63 million ha-m. The total electricity requirement by electricity operated tubewells for irrigation operations in Kharif season from June to October was found 1469.00 million $\mathrm{kWh}$ and during Rabi season from November to May its requirement was 238.40 million $\mathrm{kWh}$. The energy requirements for Aurangabad district was found 536.91 million $\mathrm{kWh}$ which was highest among the study area. The energy expenditure in the month of June was found maximum and least in the month of May. The average electricity requirements to apply one hectare meter of water (Irrigation Energy Intensity) in study area was 696.79 $\mathrm{kWh} / \mathrm{ha}-\mathrm{m}$.

\section{Introduction}

Indian population about more than $65 \%$ is mainly dependent on agriculture and its related activities. Crops need water which is the most essential key inputs, sufficient and well-timed supply of which is compulsory all through the crop growing stage for their optimum growth. Due to inadequate and uneven distribution of rainfall during the growth period of crops it becomes necessary to apply additional water to the soil in the form of irrigation for plant use. Irrigation consumes large amount of water and energy. The growth of agriculture has been possible because of timely and adequate supply of 
water as a result ground water irrigation started assuming greater importance as compared to canal irrigation. During current year, Indian agricultural has knowledgeable phenomenal increase in mechanization so, the energy requirements have increased many times. A very conventional estimation reveals the necessity of about 68 billion $\mathrm{kWh}$ of electricity for Indian agriculture by the year 2020 (Panesar, 2000). Electricity in the agricultural sector is generally used in pumping water for irrigating the land for operating farm machines etc. In India the percentage share of electricity consumption by agriculture sector has increased significantly from 3.9 per cent in $1950-51$ to 21.73 per cent in 2005-06.

The energy demand per hectare of irrigated land varies with the amount of water needed for crop growth, the depth of pumped water and the type of irrigation system. This is very serious for a country like India where agriculture sector contributes 18 per cent towards GDP and employs about 56.6 per cent of the total population. Therefore, to avoid any adverse effect to the national economy, proper planning of energy requirements in the agricultural sector is very essential.

The present study is designed to calculate energy demands for irrigation operations and reveal its applications through the modelling combining the numerous equations and correlations. The data used were collected from the previous years' crop production history and literature. The model effectively calculated the amount of water needed and the energy expenditure.

\section{Materials and Methods}

The brief description of the study area, ENIRRMOD (Energy IRRigation MODel) model used for estimation of energy requirements (Bhagat, 2001), collection of data and procedures followed in determining various components of energy requirements for irrigation operation are discussed in following sub-sections.

\section{Irrigation water requirement and energy demand}

The assessment of irrigation water requirement involves combining evapotranspiration with effective rainfall and miscellaneous water requirements that must be supplied during irrigation for a winning crop production (Fig. 1). The irrigation water requirements for a crop season can be predictable from the water balance equation, written for the volume of root zone and plant canopy (Svehlik 1987). For water requirement the formulas, correlations and different values for parameters have been written in Table 1 are used for the evaluation of water and energy requirements.

\section{Energy requirements for irrigation operation}

ENIRRMOD (Energy IRRigationMODel) model used for estimation of energy requirements (Bhagat, 2001), collection of data and procedures followed in determining various components of energy requirements for irrigation operation.

\section{Results and Discussion}

\section{Irrigation water requirements}

The quantity of irrigation water essential to meet the irrigation water needs of crop was estimated by using equation (10). Based upon the area under different crops, area wise ground water pumpage is given in Table 2 . The total crop water requirement of area and ground water pumpage irrigated by electricity operated tubewells in state can be found for different months. 
Table.1 Expressions for ground water pumpage Formula/ Correlation
$\mathrm{I}_{\mathrm{n}}=\mathrm{ET}_{\mathrm{m}}-\mathrm{ER}+\mathrm{W}_{\mathrm{n}}+\mathrm{W}_{\mathrm{c}}+\mathrm{W}_{\mathrm{s}}---$--o-
$\mathrm{I}_{\mathrm{n}}$ is Net irrigation water requirement in $(\mathrm{mm}), \mathrm{ET}_{\mathrm{m}}$ is Crop evapotranspiration in $(\mathrm{mm})$, ER
is Effective rainfall in $(\mathrm{mm}), \mathrm{Wn}$ is Water requirement for seed bed preparation and other special
needs in $(\mathrm{mm}), \mathrm{W}_{\mathrm{c}}$ is Upward movement of water into the root zone $(\mathrm{mm}), \mathrm{W}_{\mathrm{s}}$ is Carry over soil
moisture $(\mathrm{mm}) ;$

$\mathrm{I}_{\mathrm{n}}=\mathrm{ET}_{\mathrm{m}}-\mathrm{ER}+\mathrm{W}_{\mathrm{n}}$

Under normal conditions, contribution of upward movement of water into the root zone $\left(\mathrm{W}_{\mathrm{c}}\right)$ and carry over soil moisture $\left(\mathrm{W}_{\mathrm{s}}\right)$ to seasonal water requirement is negligible.

$\left(1-\frac{\mathrm{Y}_{\mathrm{z}}}{\mathrm{Y}_{\mathrm{m}}}\right)=\mathrm{K}_{\mathrm{y}}\left(1-\frac{\mathrm{ET}_{\mathrm{z}}}{\mathrm{ET}_{\mathrm{m}}}\right)$

Ya is Actual crop yield (tonne/ha), Ym is Maximum potential crop yield at ETm (tonne/ha), Ky is Crop yield response factor, ETa is Actual evapotranspiration (mm), ETm is Crop evapotranspiration $(\mathrm{mm})$.

Experimental values of Ky for different crops given by Doorenbos and Kassam (1979); Ky is 1.1 (rice), 1.0 (wheat), 1.3 (maize), 1.2 (sugarcane), 1.1 (Potato). Actual crop yields (Ya) of 2010-11 for major irrigated crop of selected area were obtained from related departments. The maximum attainable yield $\left(\mathrm{Y}_{\mathrm{m}}\right)$ for a given crop, grown under farming conditions, can be estimated from existing local record in the area under consideration.

$\mathrm{IR}=\mathrm{ET}_{\mathrm{a}}-\mathrm{ER}+\mathrm{W}_{\mathrm{n}}$

IR is the average amount of irrigation water applied and used to meet water demands of plants.

$\mathrm{IR}=\left[1-\frac{1}{\mathrm{~K}_{\mathrm{y}}}\left(1-\frac{\mathrm{Y}_{\mathbf{z}}}{\mathrm{Y}_{\mathrm{m}}}\right)\right] \mathrm{ET}_{\mathrm{m}}-\mathrm{ER}+\mathrm{W}_{\mathrm{n}}$

$\mathrm{W}_{\mathrm{n}}=\sum_{\mathrm{i}=1}^{3} W_{i}$

(5) (using eqn. 3 and 4)

$\mathrm{W}_{1}$ is Amount of water required for nursery raising for rice crop $(\mathrm{mm}), \mathrm{W}_{2}$ is Water requirement for seed bed preparation $(\mathrm{mm}), \mathrm{W}_{3}$ isDeep percolation loss in rice fields $(\mathrm{mm})$.

$\mathrm{IR}_{\mathrm{s}}=\frac{\mathrm{IR}}{\eta_{\mathbf{a}} \times \eta_{\mathrm{c}}}$

IRs is amount of water drawn from the water source; $\eta_{\mathrm{a}}$ : water application efficiency (is the ratio of quantity of water stored in the root zone of the crops to the quantity of water delivered to the fields.); $\eta_{\mathrm{c}}$ : water conveyance efficiency (It is the ratio of quantity of water delivered to the fields to the quantity of water diverted from the source.)

$$
\begin{aligned}
& \mathrm{IR}_{\mathrm{s}}=\frac{1}{\eta_{\mathbf{z}} \times \eta_{\mathrm{c}}}\left[\left\{1-\frac{1}{\mathrm{~K}_{\mathrm{y}}}\left(1-\frac{\mathrm{Y}_{\mathbf{2}}}{\mathrm{Y}_{\mathrm{m}}}\right)\right\} \mathrm{ET}_{\mathrm{m}}-\mathrm{ER}+\eta_{\mathrm{l}} \sum_{1=1}^{3} \mathbf{W}_{1}\right] \\
& \mathrm{a}_{\mathrm{t}}=\mathrm{P}_{\mathrm{i}} \times \mathrm{a} \\
& \mathrm{Q}=\frac{0.001 \mathrm{a}_{\mathrm{t}}}{\eta_{\mathrm{g}} \times \eta_{\mathrm{c}}}\left[\left\{1-\frac{1}{\mathrm{~K}_{\mathrm{y}}}\left(1-\frac{\mathrm{Y}_{\mathrm{z}}}{\mathrm{Y}_{\mathrm{m}}}\right)\right\} \mathrm{ET}_{\mathrm{m}}-\mathrm{ER}+\eta_{\mathrm{g}} \sum_{\mathrm{i}=1}^{3} \mathrm{~W}_{\mathrm{1}}\right] \\
& \left.\mathrm{Q}=\frac{0.001 \mathrm{a}_{\mathrm{t}}}{\eta_{\mathbf{l}} \times \eta_{\mathrm{c}}}\left[\left\{1-\frac{1}{K_{y}}\left(1-\frac{Y_{a}}{Y_{\mathrm{m}}}\right)\right\} \mathrm{ET}_{\mathrm{m}}-\mathrm{ER}\right\} \mathrm{S}+\eta_{\mathrm{l}} \sum_{\mathrm{I}=1}^{3} \mathbf{W}_{1}\right]
\end{aligned}
$$

$\mathrm{Q}$ is total amount of water required (ha-m), a is Irrigated area of crop (ha), $\mathrm{P}_{\mathrm{i}}$ is Fraction of tubewells irrigated area (per cent), $\mathrm{a}_{\mathrm{t}}$ is Tubewell irrigated area (ha), $\mathrm{S}$ is Soil factor for the area.

$\operatorname{ET}_{\mathrm{m}}(\mathrm{j})=\mathrm{K}_{\mathrm{c}}(\mathrm{i}, \mathrm{l}) \times \operatorname{ETo}(1, \mathrm{j})$

$\operatorname{ET}_{\mathrm{o}}(1, \mathrm{j})=5.625\left\{\mathrm{e}_{\mathrm{amax}}(\mathrm{l}, \mathrm{j})-\mathrm{e}_{\mathrm{amin}-2} 2(1, \mathrm{j})\right\}$

ETo $(l, j)$ is Reference evapotranspiration in $1^{\text {th }}$ month for $j^{\text {th }}$ district $(m m)$, ETm $(j)$ is total crop evapotranspiration for $\mathrm{j}^{\text {th }}$ district $(\mathrm{mm}), \mathrm{e}_{\mathrm{amax}}$ is Saturated vapour pressure in millibar at monthly maximum air temperature in $c^{0}, e_{a m i n-2}$ is Saturated vapour pressure in millibar at monthly minimum air temperature minus $2 \mathrm{c}^{\mathrm{o}}, \mathrm{Kc}(\mathrm{i}, \mathrm{l})$ is Crop co-efficient for $\mathrm{i}^{\text {th }}$ crop in $\mathrm{l}^{\text {th }}$ month.

$\mathrm{ER}=\mathrm{f}(\mathrm{D})\left[1.25 \mathrm{P}^{0.824}-2.98\right] .10^{0.0000955 \mathrm{ETm}}$

$\mathrm{f}(\mathrm{D})=1.0$ for $\mathrm{D} \leq 75 \mathrm{~mm}$;

$$
=\left\{0.53+0.0116 \mathrm{D}-8.94 \times 10^{-5} \mathrm{D}^{2}+2.32 \times 10^{-7} \mathrm{D}^{3} \text { for } \mathrm{D}>75 \mathrm{~mm}\right.
$$

ER is Monthly effective rainfall $(\mathrm{mm}), \mathrm{D}$ is Depth of water depletion in root zone prior to precipitation $(\mathrm{mm}), \mathrm{P}$ is Actually monthly rainfall $(\mathrm{mm})$;
(Prihar and

Sandhu 1987)

Authors

Here, $\eta_{\mathrm{c}}=75 \%$, $\mathrm{\eta}_{\mathrm{a}}=50 \%$ 1992)

Papadakis (1965)

USDA- SCS (1970) method
Svehlik 1987

(Sandhu et al. 
Table.2 Irrigation energy intensity for electricity operated tubewells irrigated area during 2010-11

\begin{tabular}{|c|c|c|c|}
\hline District & $\begin{array}{c}\text { Ground water pumpage } \\
(\mathbf{h a - m )}\end{array}$ & $\begin{array}{c}\text { Energy requirement } \\
(\mathbf{k W h})\end{array}$ & $\begin{array}{c}\text { Energy Intensity } \\
\text { (kWh/ ha-m) }\end{array}$ \\
\hline Gaya & 334772.23 & 237457374.11 & 684.60 \\
\hline Arwal & 804138.27 & 613938319.75 & 641.74 \\
\hline Jehanabad & 117062.83 & 85725202.97 & 686.39 \\
\hline Nawada & 31655013 & 233366611.51 & 669.22 \\
\hline Aurangabad & 718144.02 & 536914361.76 & 701.97 \\
\hline Average & & & $\mathbf{6 9 6 . 7 9}$ \\
\hline
\end{tabular}

Table.3 Season wise energy requirements for electricity operated tubewells irrigated area during 2010-11

(million $\mathrm{kWh}$ )

\begin{tabular}{|c|c|c|c|c|c|c|}
\hline \multirow{2}{*}{ Months } & Gaya & Jehanabad & Arwal & Nawada & Aurangabad & Total \\
\hline June & 129.37 & 29.06 & 578.29 & 125.03 & 351.96 & 1213.70 \\
\hline July & 16.09 & 3.93 & 8.05 & 14.97 & 45.89 & 88.94 \\
\hline August & 12.37 & 3.60 & 5.67 & 11.07 & 31.25 & 63.96 \\
\hline September & 14.62 & 4.53 & 6.93 & 13.98 & 32.64 & 72.70 \\
\hline October & 6.37 & 2.57 & 3.12 & 2.58 & 15.07 & 29.71 \\
\hline Total & $\mathbf{1 7 8 . 8 2}$ & $\mathbf{4 3 . 6 9}$ & $\mathbf{6 0 2 . 0 6}$ & $\mathbf{1 6 7 . 6 2}$ & $\mathbf{4 7 6 . 8 1}$ & $\mathbf{1 4 6 9 . 0 0}$ \\
\hline
\end{tabular}

\begin{tabular}{|c|c|c|c|c|c|c|}
\hline & \multicolumn{6}{|c|}{ Rabi season } \\
\hline November & 4.90 & 2.56 & 1.25 & 4.38 & 6.05 & 19.14 \\
\hline December & 7.03 & 4.46 & 1.33 & 8.11 & 5.79 & 26.72 \\
\hline January & 9.85 & 6.17 & 1.27 & 10.59 & 10.05 & 37.94 \\
\hline February & 12.89 & 8.88 & 2.34 & 13.47 & 12.53 & 50.11 \\
\hline March & 13.14 & 11.91 & 3.45 & 18.38 & 15.80 & 62.68 \\
\hline April & 10.22 & 7.56 & 2.03 & 10.31 & 9.30 & 39.41 \\
\hline May & 0.61 & 0.50 & 0.21 & 0.51 & 0.58 & 2.40 \\
\hline Total & $\mathbf{5 8 . 6 4}$ & $\mathbf{4 2 . 0 3}$ & $\mathbf{1 1 . 8 8}$ & $\mathbf{6 5 . 7 5}$ & $\mathbf{6 0 . 1 0}$ & $\mathbf{2 3 8 . 4 0}$ \\
\hline
\end{tabular}




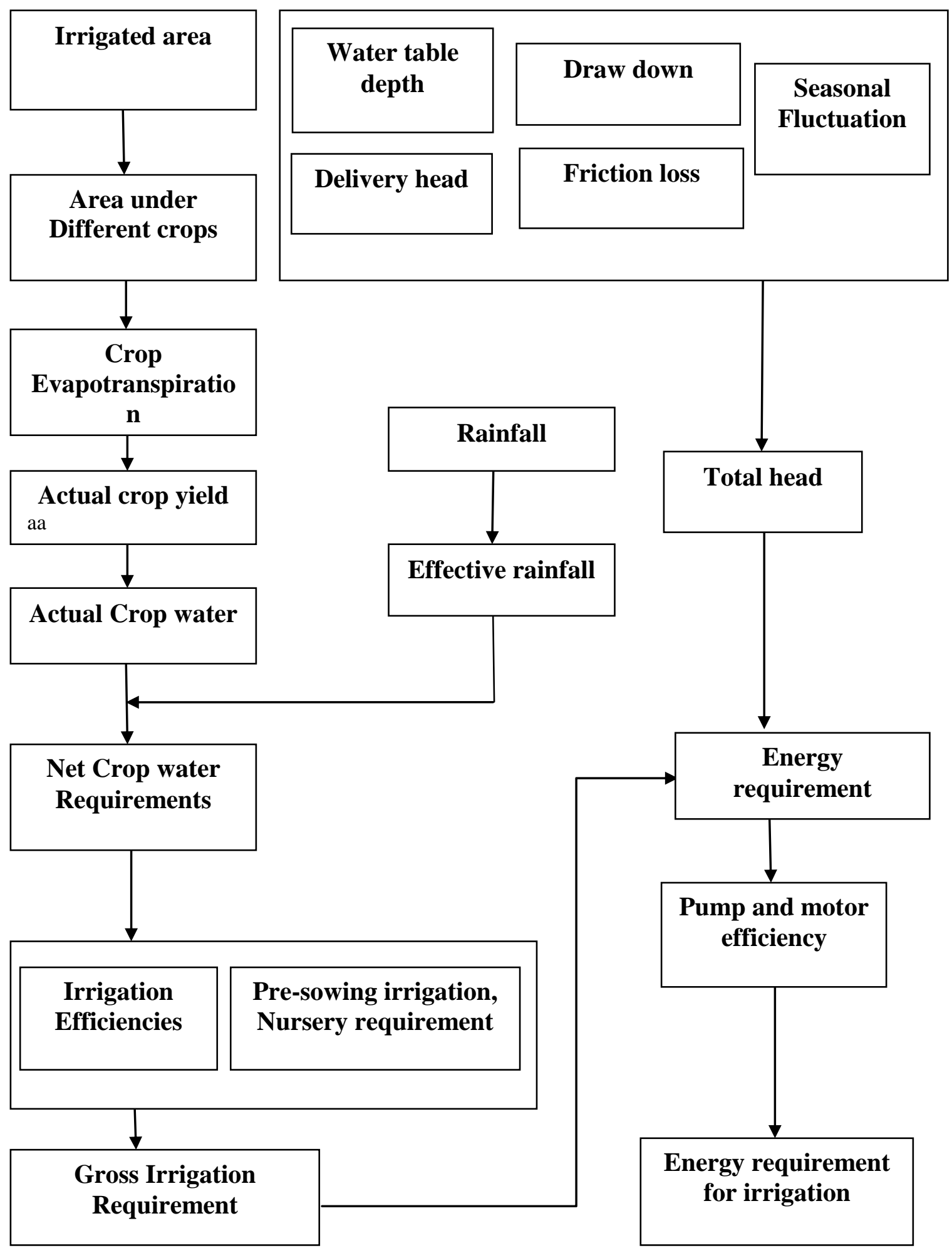

Fig.1 Flow chart for calculation of irrigation and energy requirements 


\section{Equations for calculation of energy demands by electricity operated tubewells}

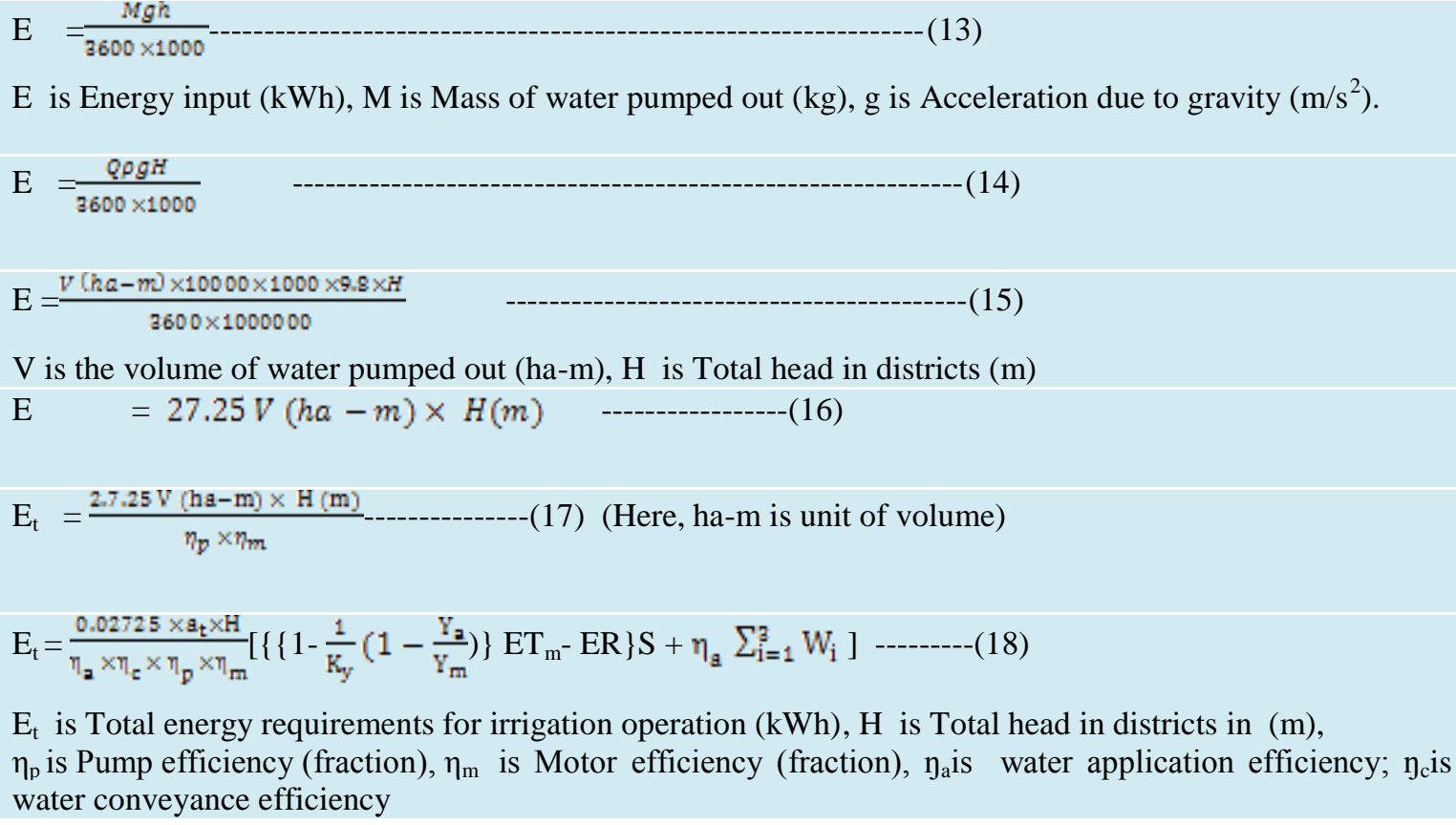

$\mathrm{E}$ is Energy input $(\mathrm{kWh}), \mathrm{M}$ is Mass of water pumped out $(\mathrm{kg}), \mathrm{g}$ is Acceleration due to gravity $\left(\mathrm{m} / \mathrm{s}^{2}\right)$.

$$
\mathrm{E}=\frac{Q \rho g H}{\square 600 \times 1000}
$$$$
\mathrm{E}=\frac{V(h \mathrm{a}-\mathrm{m}) \times 10000 \times 1000 \times 9.9 \times \mathrm{H}}{2000 \times 1000000}
$$$$
7600 \times 1000000
$$

$\mathrm{V}$ is the volume of water pumped out (ha-m), $\mathrm{H}$ is Total head in districts (m)

$$
\begin{aligned}
& \mathrm{E} \quad=27.25 \mathrm{~V}(\mathrm{ha}-\mathrm{m}) \times \mathrm{H}(\mathrm{m}) \\
& \mathrm{E}_{\mathrm{t}}=\frac{27.25 \mathrm{~W}(\mathrm{hg}-\mathrm{m}) \times \mathrm{H}(\mathrm{m})}{m_{\mathrm{p}} \times \mathrm{m}_{\mathrm{m}}} \\
& \left.\mathrm{E}_{\mathrm{t}}=\frac{0.02725 \times \mathrm{a}_{\mathrm{t}} \times \mathrm{H}}{\eta_{\mathrm{z}} \times \pi_{\mathrm{e}} \times \mathrm{m}_{\mathrm{D}} \times \mathrm{m}_{\mathrm{m}}}\left[\left\{1-\frac{1}{\mathrm{~K}_{\mathrm{y}}}\left(1-\frac{\mathrm{Y}_{\mathrm{z}}}{\mathrm{Y}_{\mathrm{m}}}\right)\right\} \mathrm{ET}_{\mathrm{m}}-\mathrm{ER}\right\} \mathrm{S}+\eta_{\mathrm{a}} \sum_{\mathrm{i}=1}^{\mathrm{g}} \mathrm{W}_{\mathrm{i}}\right]
\end{aligned}
$$

$E_{t}$ is Total energy requirements for irrigation operation $(\mathrm{kWh}), \mathrm{H}$ is Total head in districts in $(\mathrm{m})$, $\eta_{\mathrm{p}}$ is Pump efficiency (fraction), $\eta_{\mathrm{m}}$ is Motor efficiency (fraction), $\eta_{\mathrm{a}}$ is water application efficiency; $\eta_{\mathrm{c}}$ is water conveyance efficiency

This deviation in crop water necessity and hence the ground water pumpage is due to variation in area under different crop, peak water requirement of different crop.

It is initiate that on the average energy requirement about $696.79 \mathrm{kWh}$ to apply one hectare-meter of water in the South Bihar. The highest energy requirements for was found 536.91 million $\mathrm{kWh}$ in Aurangabad district. The high energy requirement is because of deep water table depth and large seasonal variation.

Energy is essential for agricultural production. To increase the production the sharp rise in demand for electricity is essential. The electricity requirement for irrigation operation is one of the principal parameters for planning, design and operation of irrigation and water resources systems (Table 3).

The study was done for the year 2010-11. Information about rainfall, climatic parameters, cropping system, crop yields, water table depth below ground surface, area cultivated under different crop were obtained from different departments and used to calculate the electricity requirements for irrigation operation. Based on the results of the study, the following conclusions could be drawn. The total ground water pumpage required for irrigation operation in the study area was found 33.63 million ha-m.

The average electricity requirements to apply one hectare meter of water (Irrigation Energy Intensity) in study area was $696.79 \mathrm{kWh} / \mathrm{ha}-$ $\mathrm{m}$. Total ground water pumpag required in study area was found 33.63 million ha-m. The total electricity requirement by electricity operated tubewells for irrigation operations in Kharif season from June to October was found 1469.00 million $\mathrm{kWh}$ and during Rabi season from November to May its requirement was 238.40 million $\mathrm{kWh}$. The energy requirements for Aurangabad district was found 536.91 million $\mathrm{kWh}$ which was highest among the study area. The energy 
expenditure in the month of June was found maximum and least in the month of May.

\section{References}

Anonymous, (2010) Agriculture and irrigation. Bihar through Figures, Fourth Biennial Publication. pp. 60-81. Directorate of Economics and Statistics, Dept. of Planning and Development Bihar, Patna.

Anonymous, (2011) Agriculture and irrigation. Bihar through Figures, Fourth Biennial Publication. pp. 51-81. Directorate of Economics and Statistics, Dept. of Planning and Development Bihar, Patna.

Gilley J R (1983) Energy utilization and management irrigation. Advances in irrigation. 2: 31-59.

Khan M A, Shingh G and Singh Gajender (1996) Energy inputs and crop production in Western Pakistan. Energy-Oxford. 21 (1): 45-53.

Malik R K and Rao A R (1983) Energy inputs to irrigation of paddy. International Journal of Tropical Agriculture, 1 (1): 65-72.

Marcolin E and Robaina A D (2002) Energy consumption and efficiency of water pumping stations to irrigate rice crop fields. Ciencia Rural, 32 (2): 229-235.

Murthy K V S R and Raju M R (2009)
Analysis on electrical energy consumption of agricultural sector in Indian context. ARPN Journal of Engineering and Applied Sciences, 4 (2): 6-9.

Papadakis J (1965) Potential evapotranspiration. Boenos Aires. PP. 54. Original not seen. Cited by Khepar S D, Narda N K and Kaushal M P (1983) Water resource utilization, cropping pattern and irrigation needs of Punjab. J Res Punjab agric Univ, 20: (4) 493-502.

Prihar S S and Sandhu B S (1987) Irrigation of Field Crops - Principle and Practices. PP. 1-142. ICAR, New Delhi.

Sandhu B S, Narda N K and Uppal H S (1992). On farm efficient management of irrigation water. Proc. Water Resources Day. PP. 104-124. PAU, Ludhiana.

Shehlik Z J (1987) Estimation of irrigation water requirement. In: Rydzewski J R (ed). Irrigation development planning. Pp 115-143. John Wileysons - Inc, N.Y.

USDA (1970) Irrigation Water Requirement. PP 1-88. Tech. Release No. 21. SCS.Engg. Div. U S Govt. Printing office, USA.

USDA (1970) Irrigation Water Requirement. PP 1-88. Tech. Release No. 21. SCS. Engg. Div. U S Govt. Printing office, USA.

\section{How to cite this article:}

Akanksha and Er. Indu Bhushan Bhagat. 2018. Energy Demands Estimation in Certain Districts of South Bihar for Irrigation Operations. Int.J.Curr.Microbiol.App.Sci. 7(02): 14711477. doi: https://doi.org/10.20546/ijcmas.2018.702.178 